\title{
THE IMAGES OF TIME IN THE EPOCH OF MULTICULTURALISM
}

\author{
Ina Nalivaika \\ Department of Philosophy of Culture, \\ Belarusian State University, \\ Nezalezhnosti Av. 4, 220030 Minsk, Belarus \\ E-mail:niminna@mail.ru
}

\begin{abstract}
The article is devoted to the comprehension of the connection between the idea and practice of multiculturalism and images of time that define the identity of classical cultural models. To answer the question about the perspectives and the limits of multiculturalism as new form of pluralism, it is necessary to examine the origins of the idea of plurality in Western culture. This idea occurs to be deeply connected with the specific movement of subjectivation and the mode of time-experience that defines the ontological basis of the Self. The specific feature of European mode of apprehension of the time is its visual character. The vivid call of the epoch of multiculturalism is the need for transformation of indefinite plurality into real diversity. It demands new ontology based on refusal from visual approach to time and on transition "eidetic" one into "existential".
\end{abstract}

Keywords: diversity, images of time, multiculturalism, multiplicity, plurality, time, subjectivation, subjectivity.

DOI: $10.3846 / 2029-0187.2008 .1 .131-138$

Oblivion is impossibility of return while memory is the necessity of revival (Gilles Deleuze).

\section{Introduction}

First of all let us start with the question why time is one of the main points of philosophical investigations nowadays? A lot of books and articles try to focus their attention on different features and meanings of the concept of time. In the framework of postclassical philosophy time becomes the corner stone of various conceptions. One can remember brilliant studies made by Edmund Husserl, Martin Heidegger, Michaił Bachtin, Emmanuel Lévinas, etc.

It seems to me that one of the most radical and the most fundamental attempts of comprehension (or even re-comprehension) of time belongs to ontological studies. Since Heidegger's works time is comprehended as one of the basic ontological conditions of our existence. According to the words of modern Russian researcher Alexei Chernyakov, contemporary philosophy tries to create something like new ontology of time.

What happened? Did we (European cultures as well) reach specific time-border where we have rather new experience of time? May be the reason is in the crisis of the great Western tradition, i.e. so called rhetoric culture, the culture of "ready word"? May be we need a different mode of the "new" than that was produced by this culture? Or "new" as permanent changing, enrolled in the time, lost its cultural importance? 
Moreover, one must answer fundamental question: why and when time may become the object of the thought. Obviously William Shakespeare prompted the most vivid answer only when the links between the times are broken. Only in this case one can notice time itself, time as event. So the problem is how we experience the event of time today, i.e. in the epoch of globalization on the one hand and the epoch of multicultural tendencies on the other? What images of time do modern culture and contemporary philosophy create?

The answer presupposes the analysis of the place of the concept of time in the classical philosophy as well as the comprehension of the images of time in previous European culture. Besides we have to indicate the connection between the mode of being and the type of time-experience in order to understand what time we are living in now. This task includes the question how our reception of time is connected with the models of subjectivity and what is the origin and specific features of the phenomenon of memory. What is the difference between individual and collective memory and what is the role of historical memory in European tradition?

The next step of our research is aimed to realize the reasons of origin and comprehension of the idea of plurality, multiplicity and diversity in Western tradition because it is the basis of modern theoretical models of multicultural situation. The problem of the influence of time-models on forming and adopting the idea of multiculturalism is the main item of our research. While the problems of ontology of time are widely discussed in the well-known works of Husserl, Heidegger, etc., the above-mentioned connection between time-models and the idea and situation of multiculturalism is just at the start-point of its theoretical comprehension.

\section{Time and temporality}

In spite of famous poetic formula that one cannot choose the times he (she) lives in, every epoch and every culture create their own mode of time-comprehension and time-experience (living-within-time). Moreover, originally the word "epoch" means "stopping", "slowing", so it may be understood as something like a barrier where Time becomes noticeable, where it manifests itself as an event or where it produces the History. Such interruptions in the eternal stream of time are the only possibility to fix the movement of subjectivity, generally speaking - to notice the Self. So these historical timemodels mark the difference between specific modes of comprehension and practicing the Self. One could speak about different ways of self-consciousness but this correlation between the Self and Time has rather ontological than gnoseological character. Definite model of time-experience corresponds to definite ontology, definite mode of existence and specific image of Being.

So we must differ between the concepts of Time and Temporality as the fundamental structure of being and the images of time, creating and experiencing by definite culture. Beside this we must take in account that the time-experience itself has ambivalent character. Everyone experience his / her own inner-time that does not coincide with so called objective (external) time. The subject of such time-experience may be 
definite person as well as definite culture. ${ }^{1}$ That's why in spite of the fact that every self is grounded in "primordial temporality", each person and each culture have their own image of time that governs their life.

\section{The concepts of time in the classical philosophy}

Nowadays the connection between Time and the Self seems to be evident but their relations have complicated history. It is the history of thought reflecting the history of the Subject. So let us start from the very beginning. With no doubt the first Western philosophical conception of time one can find in famous Parmenides poem. It was the first attempt to clarify the relationship between Being and Time. On the one hand there is evident similarity between understanding of Being and Time because both of them are understood as something eternal, present, unchangeable, in definite sense - absolute. While Being is something persistent, time is permanent "now". The presence in the present, the present as the presence - this is the only meaning of time. So Parmenides time is indistinguishable from being as presence. We can add in forward that such meaning of time coincides with old Greek understanding of truth as something eternal, as permanent presence, as something that never may be forgotten. So, ancient Greek mood is radical "no" to Chronos, "no" to everything fluent and changeable.

The second great step in Greeks' comprehension of ontology of time was made by Aristotle. Aristotle is well-known as the first thinker, whose purpose was to learn the nature and the specificity of different basic phenomena, including the nature of time. But the most interesting point is Aristotle's intention to connect time and movement. In the forth book of Physics Aristotle defines time as the number of movement in relation to the "before" and the "after". But such definition became possible only under the condition of recognizing the time as a stream, as a changing. From this point of view the most significant item is Aristotle's distinction between two modes of "now". Parmenides understanding of "now" as something permanent, equal to itself, identical is supplemented by the meaning of "now" as something fluent. Now may be understood as something that is difficult to grasp and to stop, something that is always disappearing. But alongside with this disappearance time only in Aristotle conception became noticeable. Only "passing time", time that consists of numerous unique and fluent 'now' may be perceived as specific dimension. Aristotle not only connected time with movement and number, he brought in time variety and changing. Since that time became divisible and distinguishable, it transforms into times. Moreover, this discovering of time gave origin to the appreciation of new. Only in such horizons the new had a chance to become a value.

Thus in Aristotle's time-theory "now" articulates time. Time becomes open to the future and connected with the past. It opens "before" and "after", i.e. it opens the historical

1 One of my friends told me about amusing example of such non-coinciding taken from his own everyday practice: he never managed to have dinner in Arabic restaurants because he never had patience to wait for cooking of the ordered meal. 
dimension. In other words it generates the strata of Memory. But beside this time becomes divided into "now" and "then", into so called "small" and "large" time (Бахтин 1979). All above mentioned put the basis for the comprehension of time as connected with Subject.

This theoretical tradition finds its logical conclusion in the transcendental philosophy. According to the Kant's theory time is the form of acting the reason upon itself, while space is the form of external influence on the reason. Thus time is self-influence; it creates essential structure of subjectivity.

Modern "ontology" of time (first of all Husserl's and Heidegger" works) is completion and, at the same time, the overcome of this tradition. Thus "according to Husserl, the ego cogitans "temporalizes" itself in the absolute temporal flow. This temporalization $<\ldots>$ is nothing else but the 'ever-failed' attempt of self-objectification in reflection, the endless longing for the positivity of the Self” (Черняков 2001: 458).

\section{The birth of the subject - the birth of memory}

One may presuppose that European comprehension of time originates from Greek tradition and is the reflection of the movement of subjectivity. Radical change in Greek attitude towards time that was summed up in Aristotle's philosophy was connected with the movement of subjectivation that takes its origin in specific mode of power relations.

Regarding the beginning of Western culture one can state that the immanent (public) character of power in the framework of ancient democracy defines the subjectivity with the help of self-governing experience. According to Deleuze's theory, subjectivity is the result of experiencing the power within the self, i.e. of doubling the power. In other words, it is only the fold of power. One must be able to govern himself in order to govern another. Thus subjectivity is the fold of power; the fold of external but the contours of this fold become the border and the form of subjectivity. The fold creates inner space of the self. The Greeks invented the Subject, but only as a result or the outcome of subjectivation. They created the specific mode of activity - self-influence or self-governing the kind of self-attitude that was the result of doubling power. It was that very process which opened the new dimension - the dimension of time, or more exactly - the dimension of memory. Memory is the proper name of self-attitude or subjectivity. Memory divides eternal time-stream into the events, it connects the past and the future through individually living "now". It is memory that establishes the similarity between subject and time. Memory is the form of subjective "dwelling" of the times. It marks the difference between inner time and objective time, between before and after, between history and eternity. Memory has selective character. It differs one moment from another, changing some of them into the event. So since the birth of the memory time becomes not only divisible but also visible. Time gets an image.

\section{Time as an image: visibility of time}

How strange the statement the image of the time could be, it is no pure metaphoric. The specificity of European culture is that we not only experience the time, live in it, but we see time or even read time (Michel de Certau even says about the epic of the eye), i.e. we 
perceive the world as a whole through the time-stream. We notice the signs of time in space and within ourselves. We read the time as the history - as a chain of noticeable moments represented into the space.

The source of this specificity also lies in the Ancient Greek culture with its famous cult of visible, cult of eidos. The person in the framework of this culture aspires not only to be but to be somebody, to implement himself, i.e. to reach his own borders, to implement his own form. But this form is created by and within public character of power, it expresses external limits of the Self - something that may be "touched" by the eye of the others. The form to some extent coincides with the place of the self in common space, it indicates the topos of the self. But this topology of inner and external is nothing else but time, because it is the result of the movement and differentiation. Time has its own image. This image makes the portrait of the epoch as well as the portrait of individual existence.

Frankly speaking the word "image" from the very beginning should be used only in plural. Only when time becomes the times, when it is opened by the movement of subjectivity, it becomes visible as images that are numerous and variable. Time as eternity, as absolute eternal "now" is invisible and unnoticeable, it is non-dividing and non-individual. The image of time shows not only how time is given to the subject, but also - how the subject is opened to himself. Visibility of time, time-images are the mode of self-comprehension and self-identification. So time as an image constitutes the specific topology of the self and vice versa - topography of the self is the ontology of time.

\section{Time and plurality}

Each epoch creates own image(s) of time and the implementation in the space - its own "chronotop". Time is rather different in different epochs but we can also say about numerous different images of time within one epoch. The reason is that each chronotop has its own centre - centre of vision - its own subject. The images of time reflect the mode of subjectivity and the ways of its self-comprehension and existence. The subjectivation brings to specific identity and it may be not only individual but also common, or, better to say, cultural identity. So not only individual but also culture may be comprehended as a subject. It seems to be correct to presuppose that there is definite 'isomorphism' between them. Basing on this presupposition we will try to define the character of time-image(s) in classical European culture and their connection with the idea and the practice of plurality.

We remember that European subject "was born within the space of agora", i.e. in public, common space. The subject as a fold of power is defined by a form and a border. It is 'formed' and defined by the glance from outside, from the space of public. So 'agora' presents us definite plurality of the forms of subjectivity. Plurality of forms is the basis of such type of social organization. But it is important to note that such plurality is the plurality of the forms of the same quality, it may be comprehended as diversity but the diversity in the framework of definite social unity. So classical culture does not apprehend pure plurality, it includes plural in definite experience of order, special structure.

Within such social structure the relationships between persons (subjects) transform the figures of I and Another into indefinite Either (Any). This culture understands 
Another only as identical with Me (and sooner or later brings to the transformation of any I to indefinite ME). Each subjectivity should occupy its own place but this place is defined from outside. We have the system of so called 'proper places' (Certeau 1984: xix), built by power strategies and pre-determined from outside. Time is also 'tied' by these proper places. Time as a mode of self-attitude and self-comprehension transforms in the chain of proper times, pre-described order of actions, regulated movement, in other words, in proper History. Europe creates unite great History in spite of local life-stories. Time is conquered by the Order. In such order of things plurality has no chance to become real diversity. This image of time has nothing in common with the idea of diversity as real un-similarity. (One may remember, for example, Heidegger's characteristics of Das Man). Thus classical European culture creates the idea of homogenous time. The concept of time that contributes so much to the idea of plurality becomes so far away from it.

\section{Plurality and pluralism in contemporary world: pro et contra}

The epoch of multiculturalism is obviously connected with the re-actualization and recomprehension of the idea of plurality. The processes of globalization put us in front of the problem of reserving and supporting the cultural identity. The wide stream of migration, the expansion of mass media, deep political transformations lead us far away from the epoch of national states and national cultures. Multiculturalism is the most evident answer to this request. Multiculturalism may be understood as the politics aimed on reserving and developing of cultural differences as well as connected with its theory and ideology. The subject of this article deals with the theory of multiculturalism due to our convenience that the origin and the problems of this politics may be comprehended and explained first of all on this level.

First of all let us come to an agreement on using the words. What does it mean: pluralism, plurality, multiplicity, diversity? Is there any difference between them? "Pluralism" itself can be used and understood in at least three meanings: (1) as ontological principle defining the most general mode of being; (2) as ethical principle which indicates the main conditions of coexisting of human beings; (3) as political principal that organizes the life of political subjects.

So when we speak about the transformation of pluralism in contemporary situation of global changes we must realize what "pluralism" is the topic of our discussion. My presupposition is that all these forms of pluralism are deeply connected with and depend on definite power strategies originating the movement of subjectivation and that is why the first (ontological) image of pluralism may be considered to be the basic one. From this viewpoint pluralism may be regarded as the organizing principle of the existence of modern society. One of the fundamental features of modern societies is deep transformation of social structure. As a result, in a cultural community, not isolated (individual) person, becomes a structural unit. So it is the very cultural community that becomes the subject of identity. Thus we can speak about the necessity of coexistence of the plurality or multiplicity of cultural identities. What defines their specific existence and what are the conditions of their coexistence? 
Modern situation radically transforms classical social model because we are living now in the context of cross-cultural communication of the meeting of different power strategies, rather great meeting of the East and the West. Our contemporary situation is the situation of crushing the borders and synthesis of multiple. We cannot still speak about plurality as equality of the same, similar; we stand in front of the urgency of recognizing another. New form of plurality (that would be better to call multiplicity) demands new pluralism as the principle of organization of cultural, social and political reality. The corner stone of this new pluralism must be the movement towards Another but not Either (Any) that makes it rather close to the principle of dialogism. The recognition of multiculturalism as the manifestation of this new pluralism means not only parallel existence of autonomous 'identities' but their mutual penetration and transformation. The comprehension and recognition of Another may be only dialogical that presupposes seeking for a new basis of mutual understanding.

\section{Time of multiculturalism}

In previous chapters we came to the conclusion that every culture may be understood as a subject and is defined by its own image of time. Precisely time-image is synonymous to cultural identity; it defines the "face" of the culture. Culture itself is not only any locus ${ }^{2}$, it is characterized by its own, unique time. The Chinese, Arabs, Africans, etc. inhabit modern cities all over the world, they use the same transport, visit the same shops and offices, dwell the same place. Even the borders between the districts of a city that are inhabited by different ethnic groups are not sharp nowadays. But the time, within which they are living, inner-time of culture, time-images are different. In definite sense these people, living 'here and now', are not contemporaries. They dwell common space and live through their own time, predetermined by their own cultural past, opened to their unique cultural future. Their 'now' is 'immersed' in specific history and led by historical memory, memory demarking their specific way of subjectivation. I dare to state that in spite of all fluency of time, time-images have more stable character than cultural spaces. Thus time-images are something like the guarantee of reserving of cultural identity but how can one speak about the fruitful dialogue between these cultural units? One can enter another person's home, but how can we enter another person's time (times)? Is it possible to penetrate into else's time-image? May be we have reached the border where one at last could choose the time he (she) lives in? ${ }^{3}$

Surely the latter is impossible, but the epoch of multiculturalism should be comprehended as an epoch of new great transformation of Time. The matter is not only in the necessity and possibility to see and recognize the time of another as really another time-image(s).

\footnotetext{
2 Moreover, it is rather difficult to tie specific features of modern cultures with local, topological characteristics due to the above mentioned migration processes.

3 Let us remind so called Catalonian phenomena where great amount of ex-Marxist professors became Muslims as an example.
} 


\title{
Conclusions
}

So we evidently stay in front of the urgency to overcome visual approach to time as well. Western culture opened visibility of time alongside with autonomy and borders of the self. Visible time, time as an image is local, autonomous and "closed". It is included in definite (European) "order of things" and is aimed to support and to reproduce this order. Contemporary transformation of Time crushes (or better to say penetrates) the boundary between visible, "closed" time, time-images and time living through. It is the final stage of long transition from "eidetic" to "existential" time. It breaks old order of things and makes impossible the power of "proper times". It opens new dimension of plurality - diversity as itself. Time looses its homogeneous character and becomes something like a "call" demanding difficult choice which in turn presupposes the deed and the responsibility. That's why the policy of multiculturalism as an attempt "to govern" this process of diversity-adoption very often degenerates into pure rhetoric.

\section{References}

Certeau de, M. 1984. The practice of everyday life. California: University of California Press.

Бахтин, М. 1979. Эстетика словесного творчества. Москва: Искусство.

Делез, Ж. 1997. “Складчатость или внутреннее мысли”, пер. И. Наливайко, в кн. От я к Другому: Сб. пер. по проблемам интерсубъективности, коммуникации, диалога. Минск: Менск.

Черняков, А. Г. 2001. Онтология времени. Бытие и время в философии Аристотеля, Гуссерля и Хайдеггера. СПб, Высшая религиозно-философская школа.

\section{LAIKO IVAIZDŽIAI MULTIKULTŪRALIZMO EPOCHOJE}

\author{
Ina Nalivaika
}

\section{Santrauka}

Apmąstomas multikultūralizmo ir laiko įvaizdžių, apibrèžiančių klasikinių kultūrinių modelių tapatumą, idejos ir praktikos santykis. Siekiant aptarti multikultūralizmo kaip naujos pliuralizmo formos perspektyvas ir ribas, būtina išsiaiškinti pliuralumo kaip idejos kilmę Vakarų kultūroje. Ši idejja yra itin glaudžiai susijusi su tam tikra subjektyvacija ir laiko patirtimi, neatsiejama nuo tapatybės ontologinio pagrindo. Skiriamasis europietiškojo laiko suvokimo bruožas yra pastangos ji vizualiai charakterizuoti. Multikultūralizmo epochoje neribotas pliuralumas transformuojasi į tam tikrą skirtingumą. Tam reikia naujos ontologijos, kuria remiantis būtų galima atsisakyti vizualaus požiūrio ị laiką ir taip pereiti nuo jo „eidetinès“ prie „egzistencinès“ traktuotès.

Reikšminiai žodžiai: skirtingumas, laiko įvaizdžiai, multikultūralizmas, ịvairumas, pliuralumas, laikas, subjektyvacija, subjektyvumas. 